International

Labour

Office

\title{
GLOBAL EMPLOYMENT
}

\section{TRENDS FOR WOMEN 2004}

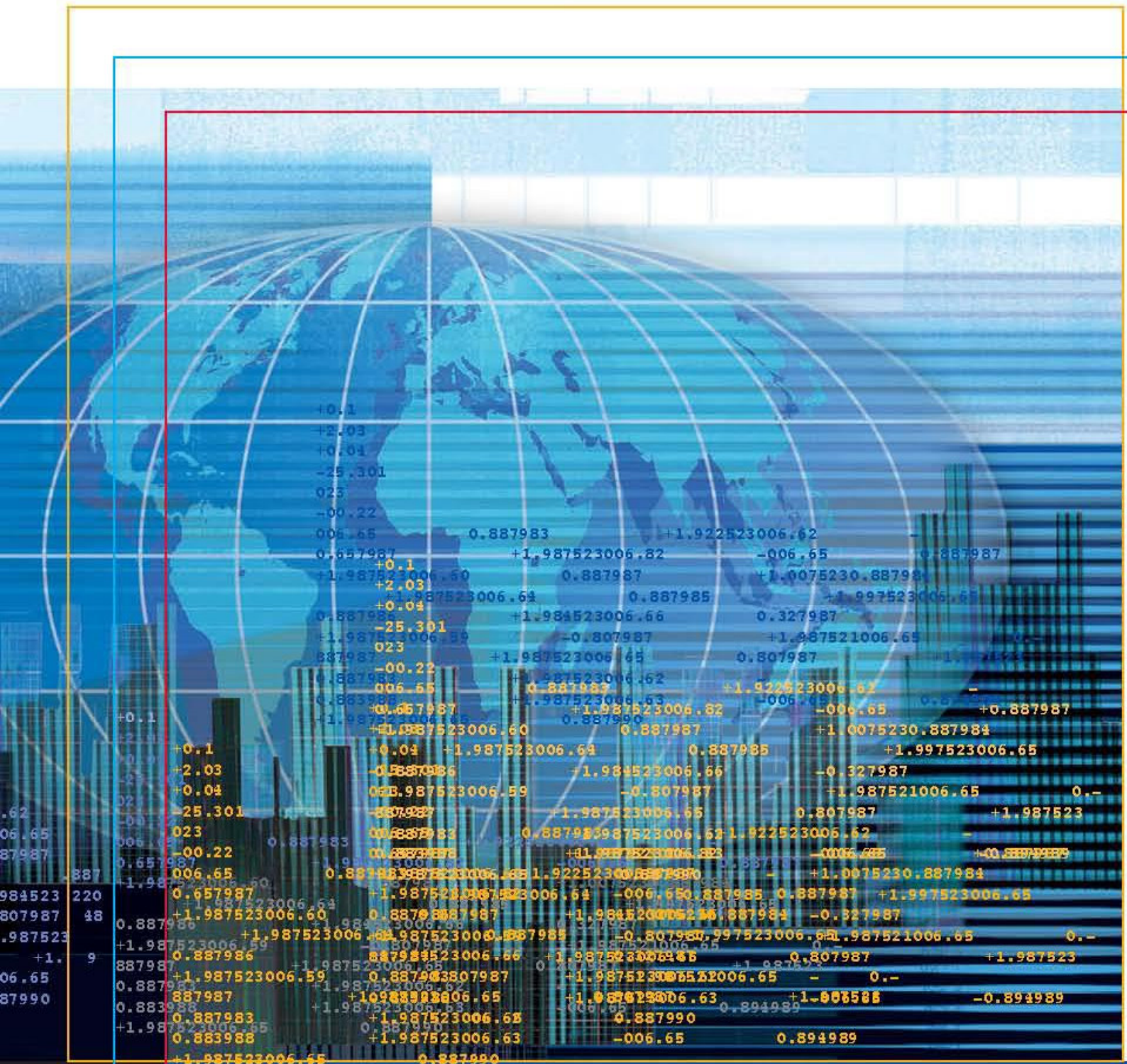

MARCH 2004 


\section{GL OBAL EMPLOYMENT TRENDS \\ F O R W O MEN}

\section{Overview}

One of the most striking phenomena of recent times has been the increasing proportion of women in the labour force, enabling women in many regions to use their potential in the labour market and to achieve economic independence. Section 2 looks at the trends in female labour force participation. But does the fact that women increasingly enter the labour market really mean that the gap between male and female participation is closing? And does it mean that women who look for work are successful in finding it? If they do find work, what are the typical characteristics of female work compared to that of male counterparts?

An analysis of six additional labour market indicators (female unemployment rates, female youth unemployment rates, employment-to-population ratios, status of employment, employment by sector and wages/earnings) makes it clear that the questions asked cannot be answered with a definitive yes. More women work today than ever before: in 2003 out of the 2.8 billion people that had work, 1.1 billion were women (table 1.1). The share of women with work in total employment has risen slightly in the past ten years to just above 40 per cent. However, improved equality in terms of quantity of male and female workers has yet to result in real socioeconomic empowerment for women, an equitable distribution of household responsibilities, equal pay for work of equal value, and gender balance across all occupations. In short, true equality in the world of work is still out of reach.

\section{Is the labour force participation gap closing?}

The labour force participation rate (LFPR) expresses the share of employed plus unemployed people in comparison with the working-age population. It gives an indication of how many people of working age are actively participating in the labour market. The gap between the LFPR for men and women has been decreasing in all regions during the past ten years. But apart from the transition economies (where 91 women are economically active per 100 men) and East Asia (with a proportion of 83 women per 100 men), all other regions still face a difference of fewer than 80 economically active women per 100 men. In the Middle East and North Africa region and also in South Asia for every 100 men in the labour force, only around 40 women are economically active (table 2.1). 
Table 1.1

Global labour market indicators, 1993 and 2003

\begin{tabular}{|l|c|c|c|c|c|c|}
\hline \multicolumn{2}{|c|}{} & \multicolumn{2}{c|}{ Female } & \multicolumn{2}{c|}{ Male } & \multicolumn{2}{c|}{ Total } \\
\hline & $\mathbf{1 9 9 3}$ & $\mathbf{2 0 0 3}$ & $\mathbf{1 9 9 3}$ & $\mathbf{2 0 0 3}$ & $\mathbf{1 9 9 3}$ & $\mathbf{2 0 0 3}$ \\
\hline Labour force (millions) & 1,006 & 1,208 & 1,507 & 1,769 & 2,513 & 2,978 \\
\hline Employment (millions) & 948 & 1,130 & 1,425 & 1,661 & 2,373 & 2,792 \\
\hline Unemployment (millions) & 58.2 & 77.8 & 82.3 & 108.1 & 140.5 & 185.9 \\
\hline & & & & & & \\
\hline Labour force participation rate (\%) & 53.5 & 53.9 & 80.5 & 79.4 & 67.0 & 66.6 \\
\hline Employment-to-population ratio (\%) & 50.4 & 50.5 & 76.1 & 74.5 & 63.3 & 62.5 \\
\hline Unemployment rate (\%) & 5.8 & 6.4 & 5.5 & 6.1 & 5.6 & 6.2 \\
\hline
\end{tabular}

Source: ILO, Global Employment Trends Model, 2003; see also ILO, Global Employment Trends 2004, Technical note.

\section{Do women who look for work find any?}

The female unemployment rate in 2003 was slightly higher than the male rate for the world as a whole (6.4 per cent for female, 6.1 per cent for male), leaving 77.8 million women who are willing to work and actively looking for work without employment. The picture is more dramatic in some regions of the world. The region that showed the greatest differential in rates was Latin America and the Caribbean with a difference of 3.4 percentage points and the Middle East and North Africa where the female unemployment rate was 6 percentage points higher than the male rate. Unemployment rates for women are lower than for men in sub-Saharan Africa (at a high level of around 10 per cent) and East Asia (at below 5 per cent).

Nor does the unemployment situation for women seem to have improved over the past ten years, with the exceptions of three regions - industrialized economies, the Middle East and North Africa and South Asia (figure 1.1). The majority of regions saw little or no change in female unemployment rates over the period 1993 to 2003. In South-East Asia the unemployment rate of women increased by more than 2 percentage points (from 4.7 per cent to 6.9 per cent).

The difficulty of finding work is even more drastic for young women (aged 15 to 24 years). Overall, 35.8 million young women are involuntarily without work. In all regions youth unemployment rates for both sexes are higher than adult unemployment rates. Again in all regions except East Asia and sub-Saharan Africa the regional female rate exceeds the male rate.

Employment-to-population ratios reflect the capacity of an economy to provide employment for the working-age population (generally 15 years and older). They can also be interpreted as an indication of how efficiently economies make use of the productive potential of their working-age population. In all regions of the world, employment-to-population ratios are much smaller for women than for men. The difference is devastating in the Middle East and North Africa where only two out of every ten women at working-age work (compared to seven out of ten for men). The situation is only slightly better in South Asia. 
Figure 1.1

Female unemployment rates, by region, 1993 to 2003

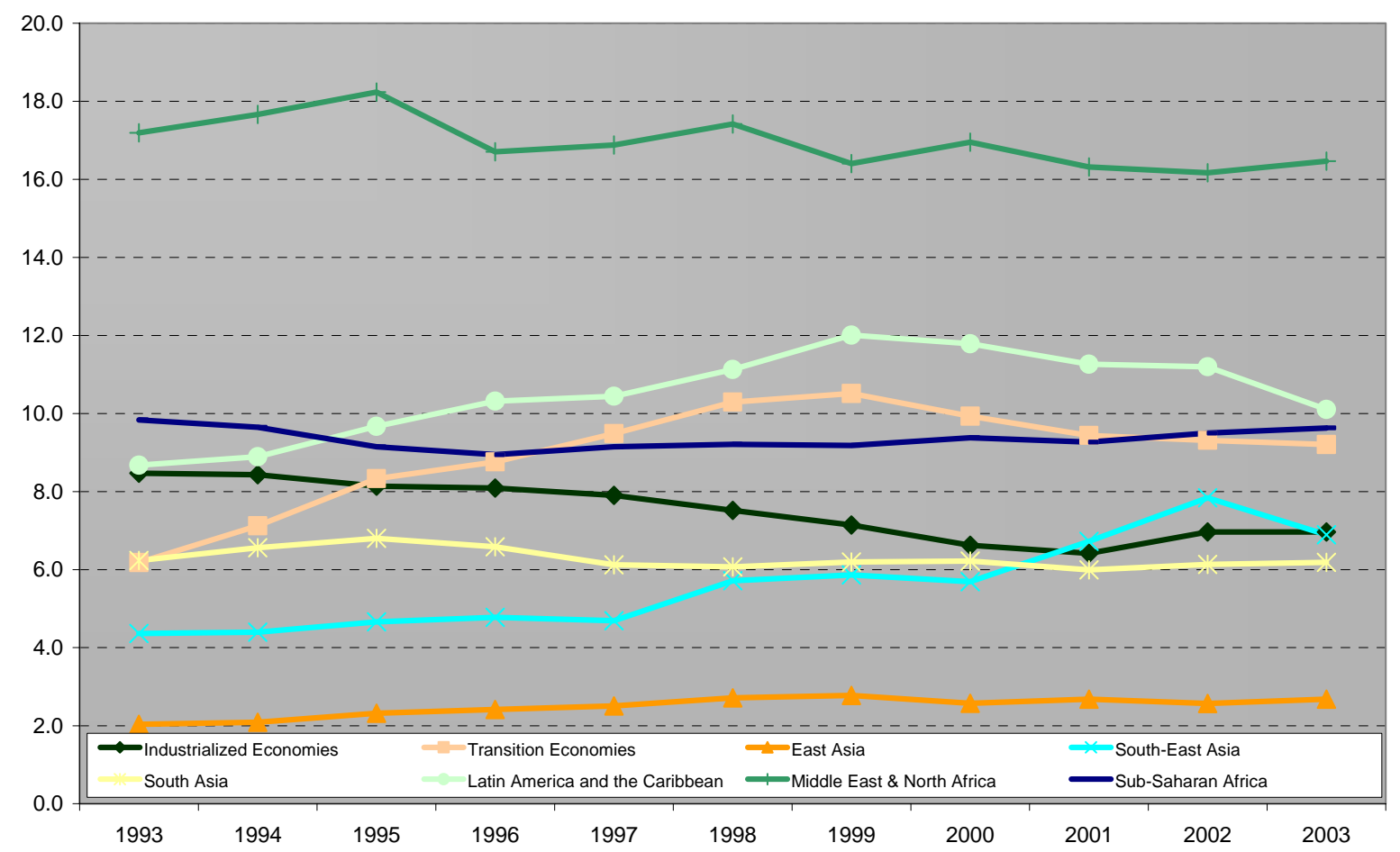

Source: ILO, Global Employment Trends Model, 2003; see also ILO, Global Employment Trends 2004, Technical note.

\section{What characterizes female work?}

Women have a smaller likelihood of being in regular wage and salaried employment than men. Also, the female share of contributing family workers exceeds the male rate in almost all economies where data are available. In economies with a high share of agriculture, women work more often in this sector than men. Women's share of employment in the services sector also exceeds that of men. Additionally, women are more likely to earn less than men for the same type of work, even in traditionally female occupations.

The results of the analysis of the three indicators (status, sector and wages/earnings) underlines the fact that women are more likely to find employment in the informal economy than men, outside legal and regulatory frameworks, with little, if any, social security benefits and a high degree of vulnerability. (See box 4.1 for more information on the informal economy.)

As a consequence, women have a higher share in the number of working poor in the world - those people who work but do not earn enough to lift themselves and their families above the US $\$ 1$ a day poverty line. Out of the 550 million working poor in the world, an estimated 330 million are women - a share of 60 per cent. ${ }^{1}$ Adding the 330 million female working poor to the 77.8 million women who are unemployed means that at least 400 million decent jobs would be needed to satisfy women's demand for decent work. It is probably safe to say that even this is a conservative estimate and if one were to address the issue of women who are involuntarily outside the labour force, the deficit of decent work opportunities for

${ }^{1}$ The claim that 60 per cent of the total working poor are women is derived from a basic assumption that the distribution by sex of world poverty is approximately one-third men and two-thirds women. See, for example, UNDP, Human Development Report 1995. The 1995 UNDP report, in fact, placed the number at 70 per cent. It is important to note, however, that this so-called "feminization of poverty" has yet to be resolutely substantiated by the data and the assumption is not without its detractors. See also footnote 5. 
women would be even greater. Creating adequate decent work for women is only possible if policy-makers not only place employment at the centre of social and economic policies but also recognize that women's problems in the world of work are even more substantial than men's. Unless progress is made to take women out of working poverty by creating employment opportunities to help them secure productive and remunerative work in conditions of freedom, security and human dignity and thereby giving women the chance to work themselves out of poverty, the UN Millennium Development Goal (MDG) of halving poverty by 2015 will not be reached in most regions in the world.

\section{Trends in female labour force participation}

The growing proportion of women in the labour force has been one of the most striking labour markets trends of recent times especially in the 1980s and to a lesser extent until today. Never before have so many women been economically active: the female labour force (the sum of unemployed plus employed women) was 1.2 billion women in 2003 up from 1 billion in 1993 (table 1.1). In addition, the LFPR for men has decreased in most regions of the world. As a result, the gap between the sexes in terms of labour force participation rates has decreased considerably. Still, in no region of the world is the gender gap anywhere near to being closed.

Figure 2.1

Labour force participation rates, by sex and region, 1993 and 2003

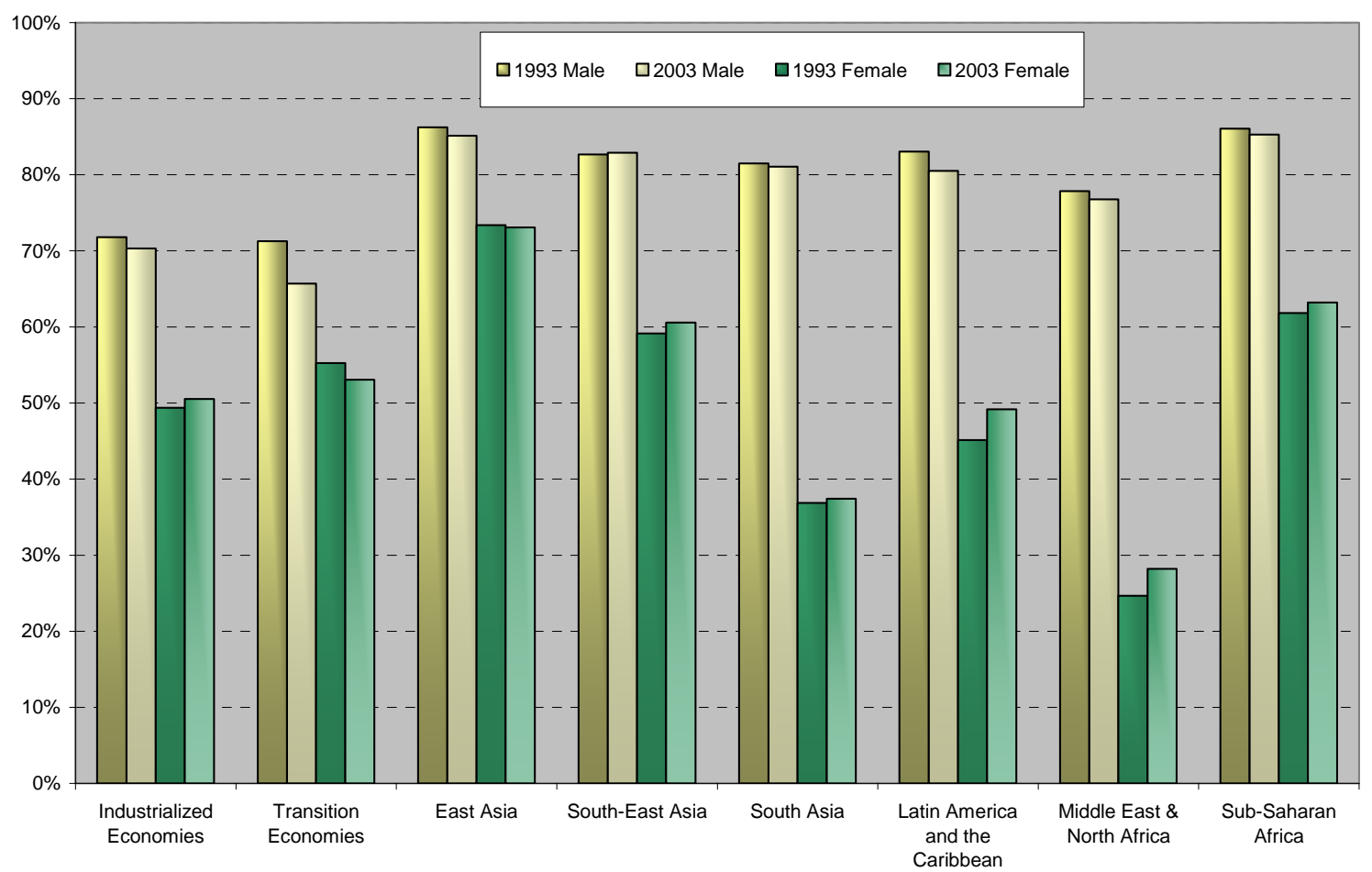

Source: ILO, Global Employment Trends Model, 2003; see also ILO, Global Employment Trends 2004, Technical note. 
Table 2.1

Male and female labour force participation rates (\%) and the gender gap in economically active females per 100 males, 2003

\begin{tabular}{|l|c|c|c|}
\hline & $\begin{array}{c}\text { Male LFPR } \\
\mathbf{( \% )}\end{array}$ & $\begin{array}{c}\text { Female LFPR } \\
\mathbf{( \% )}\end{array}$ & $\begin{array}{c}\text { Gender gap in } \\
\text { economically active } \\
\text { females per 100 } \\
\text { males }\end{array}$ \\
\hline World & 79.4 & 53.9 & 68 \\
\hline Middle East and North Africa & 76.8 & 28.2 & 36 \\
\hline South Asia & 81.1 & 37.4 & 44 \\
\hline Latin America and the Caribbean & 80.5 & 49.2 & 64 \\
\hline Industrialized Economies & 70.3 & 50.5 & 76 \\
\hline Transition Economies & 65.7 & 53.1 & 91 \\
\hline South-East Asia & 82.9 & 60.5 & 75 \\
\hline Sub-Saharan Africa & 85.3 & 63.2 & 77 \\
\hline East Asia & 85.1 & 73.1 & 83 \\
\hline
\end{tabular}

Source: ILO, Global Employment Trends Model, 2003; see also ILO, Global Employment Trends 2004, Technical note.

In 2003 for the world as a whole there were only 63 women in the labour force per every 100 men. The gap is the largest in the Middle East and North Africa (where there were 36 economically active women per 100 men) and in South Asia (where 44 women per 100 men were active). At the same time, these two regions showed the lowest female LFPR: only about one working-age woman in three was either working or looking for work, leading to participation rates of only 28.2 per cent in the Middle East and North Africa and 37.4 per cent in South Asia. This was most likely the result of the traditional role placed on women in many economies in these regions. In contrast, East Asia had the highest female LFPR and at the same time a small gender gap between the male and female LFPR (83 women in the labour force per 100 men) (table 2.1 and figure 2.1). Women's participation in the labour force in relation to fertility is discussed in box 2.1 .

It is important to keep in mind that either an increase in or a high level of LFPR per se does not always have positive connotations. The LFPR in itself does not indicate anything regarding (a) the likelihood of being employed (see section 3 on unemployment rates and employment-to-population ratios) and (b) the characteristics of work (see section 4 on status of employment, employment by sector and wages/earnings). 


\section{Box 2.1 \\ Labour force participation and fertility}

The experience of industrialized economies suggests that increased employment of women is likely to go hand in hand with sustained declines in fertility rates. This is confirmed by the data in the table below, showing a decline in fertility in all regions of the world between 1995 and 2000 and, in most cases, an accompanying increase in the likelihood of women working.

High fertility rates can give an indication that labour markets are not sufficiently attractive for women to enter as an alternative to playing their traditional role as stay-at-home mother and care-giver. Research has shown that women find it more attractive to work instead of having many children when at least one of the following conditions applies:

- Women's employment is "empowering" or "status enhancing”, so that women have control over income and resources, and a greater say in family decision-making, including fertility decisions.

- The opportunity costs for staying at home and having children increases as women are able to find wellpaid jobs.

- The returns and satisfaction that women derive from participating in economic activities are substantially higher than the returns and satisfactions of having additional children.

- Women become less dependent on children as a form of security for old age or against adverse economic conditions.

- Women's economic role and contribution to family welfare lead to reduced sex preferences for children and changing attitudes towards the value of daughters.

- Women's increasing participation in the labour force is linked to increasing investments in girls' education.

- Women have the opportunity to work and build up careers before marriage, leading to an age increase for the first marriage and pregnancy.

In some developing economies fertility rates declined but still remained at a level above the reproduction rate, indicating that not enough of the conditions mentioned above are in place. In South Asia and the Middle East and North Africa, for example, fertility rates remained relatively high in 2000 at 4.2 and 3.6 respectively, whereas female labour force participation in the regions rated amongst the world's lowest. In contrast, in subSaharan Africa, female labour force participation was very high (63 per cent), accompanied by the highest fertility rates in the world. In this region, where there are no social safety nets and low household incomes, women simply cannot afford not to work despite a heavy family burden.

Fertility rates and labour force participation rates of women, 1995 and 2000

\begin{tabular}{|c|c|c|c|c|c|c|}
\hline & \multicolumn{2}{|c|}{$\begin{array}{c}\text { Female LFPR } \\
(\%)\end{array}$} & \multirow[t]{2}{*}{ Change } & \multicolumn{2}{|c|}{$\begin{array}{l}\text { Total fertility } \\
\text { rate (births per } \\
\text { woman) }\end{array}$} & \multirow[t]{2}{*}{ Change } \\
\hline & 1995 & 2000 & & 1995 & 2000 & \\
\hline Industrialized Economies & 50.0 & 50.7 & + & 1.7 & 1.7 & none \\
\hline Transition Economies & 52.6 & 52.3 & - & 1.9 & 1.6 & - \\
\hline East Asia & 73.8 & 73.5 & - & 1.9 & 1.7 & - \\
\hline South-East Asia & 59.1 & 60.1 & + & 3.6 & 3.2 & - \\
\hline South Asia & 36.9 & 38.0 & + & 4.6 & 4.2 & - \\
\hline Latin America and the Caribbean & 46.5 & 49.0 & + & 2.9 & 2.7 & - \\
\hline Middle East and North Africa & 26.0 & 27.9 & + & 4.1 & 3.6 & - \\
\hline Sub-Saharan Africa & 61.9 & 63.0 & + & 5.5 & 5.1 & - \\
\hline
\end{tabular}

Sources: Background paper "Female labour force participation” prepared by Lin Lean Lim for the United Nations Population Division, Expert Group Meeting on Completing the Fertility Transition, held in March 2002. All papers are available at website:

http://www.un.org/esa/population/publications/completingfertility/completingfertility.htm. Labour force participation rates are from ILO, Global Employment Trends Model, 2003 and fertility rates from 


\section{Trends in female unemployment and employment-to-population ratios}

\section{Female unemployment and female youth unemployment}

More women as a proportion of their labour force are seeking work but unable to find it than men in almost all regions of the world, resulting in a global female unemployment rate of 6.4 per cent compared to 6.1 per cent for men in 2003. Only in East Asia and sub-Saharan Africa did the regional male unemployment rate exceed that of the female (the rates are equal in the transition economies) (figure 3.1). The regions that showed the greater differential in rates were Latin America and the Caribbean, where the female unemployment rate was 10.1 per cent, compared to the male rate of 6.7 per cent, and the Middle East and North Africa where the female unemployment rate of 16.5 per cent was 6 percentage points higher than the male rate of 10.6 per cent. The female-to-male unemployment rate gap was even wider in the subregions of the Caribbean (female, 14.5 per cent; male, 7.3 per cent) and North Africa (female, 16.2 per cent; male, 8.4 per cent).

The difficulty of finding work is even more drastic for young females (aged 15 to 24 years). Being female and being young can represent a double source of discrimination - young women appear to have the greatest difficulty in entering the labour market and retaining their jobs in periods of economic downturn. Youth unemployment rates for both sexes are higher than adult unemployment rates in all regions of the world (figure 3.2). Again, in all regions except East Asia and sub-Saharan Africa the regional female rate exceeded that of the male rate. Also, in keeping with the trend for the total unemployment rate, the regions of Latin America and the Caribbean and the Middle East and North Africa showed the greatest difference between the unemployment rates for young women and young men.

It is important to note that unemployment information in itself is a rather limited indicator for the inadequacy of the labour market situation, and should not be used in isolation of other indicators such as employment-to-population ratios, employment by status and sector data, as well as wage and earning indicators. Many national definitions of unemployment exclude persons who want to work but do not actively "seek" work either because they feel that no work is available to them or because such persons have restricted labour mobility, or face discrimination or structural, social or cultural barriers. These are the so-called "discouraged workers", the majority of which are generally women. Although data on discouraged workers are hard to come by, a review of the data available for industrialized economies revealed that females made up approximately two-thirds of total discouraged workers in Australia, Austria, Belgium, Germany, Greece, the Netherlands, Norway and Portugal and the female share of total discouraged workers was near 90 per cent in Italy and Switzerland. ${ }^{2}$

Caution is therefore needed in interpreting a trend of falling unemployment for women because it could indicate a situation in which women are adjusting to deteriorating economic conditions by opting out of the labour market altogether or by accepting shorter working hours rather than not working at all.

\footnotetext{
${ }^{2}$ OECD, Employment Outlook June (Paris, 2003).
} 
Figure 3.1

World and regional unemployment rates, by sex, 2003

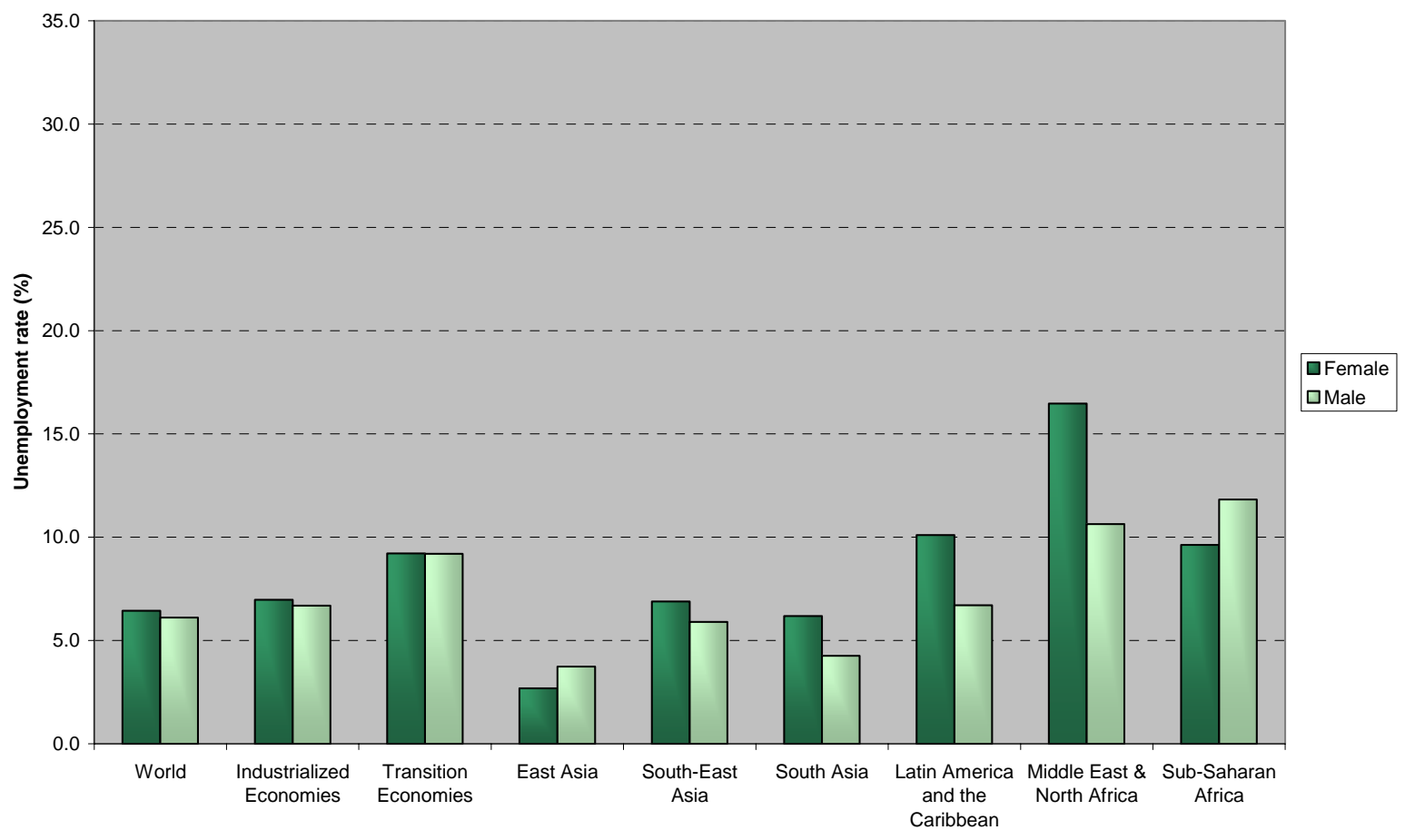

Figure 3.2

World and regional youth unemployment rates, by sex, 2003

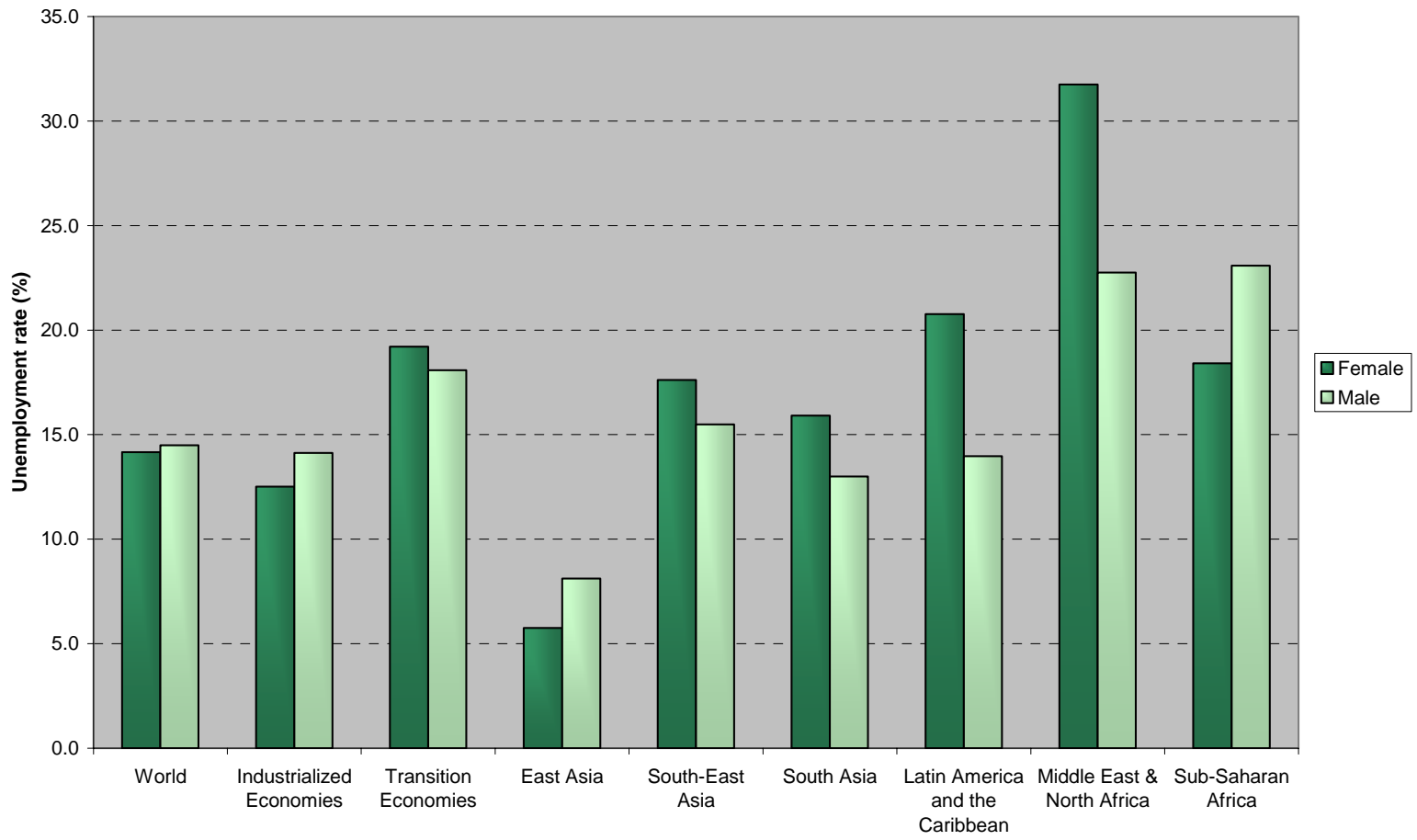

Source: ILO, Global Employment Trends Model, 2003; see also ILO, Global Employment Trends 2004, Technical note. 


\section{Trends in employment-to-population ratios}

Employment-to-population ratios indicate the capacity of economies to create employment opportunities for their population - the higher employment-to-population ratio, the more people in the working-age population are working. As figure 3.3 shows, this indicator is higher for men in all regions of the world. Also in all regions the ratios for women have increased during the past ten years, but the gap persists.

\section{Figure 3.3}

Differential between male and female employment-to-population ratios, 2003

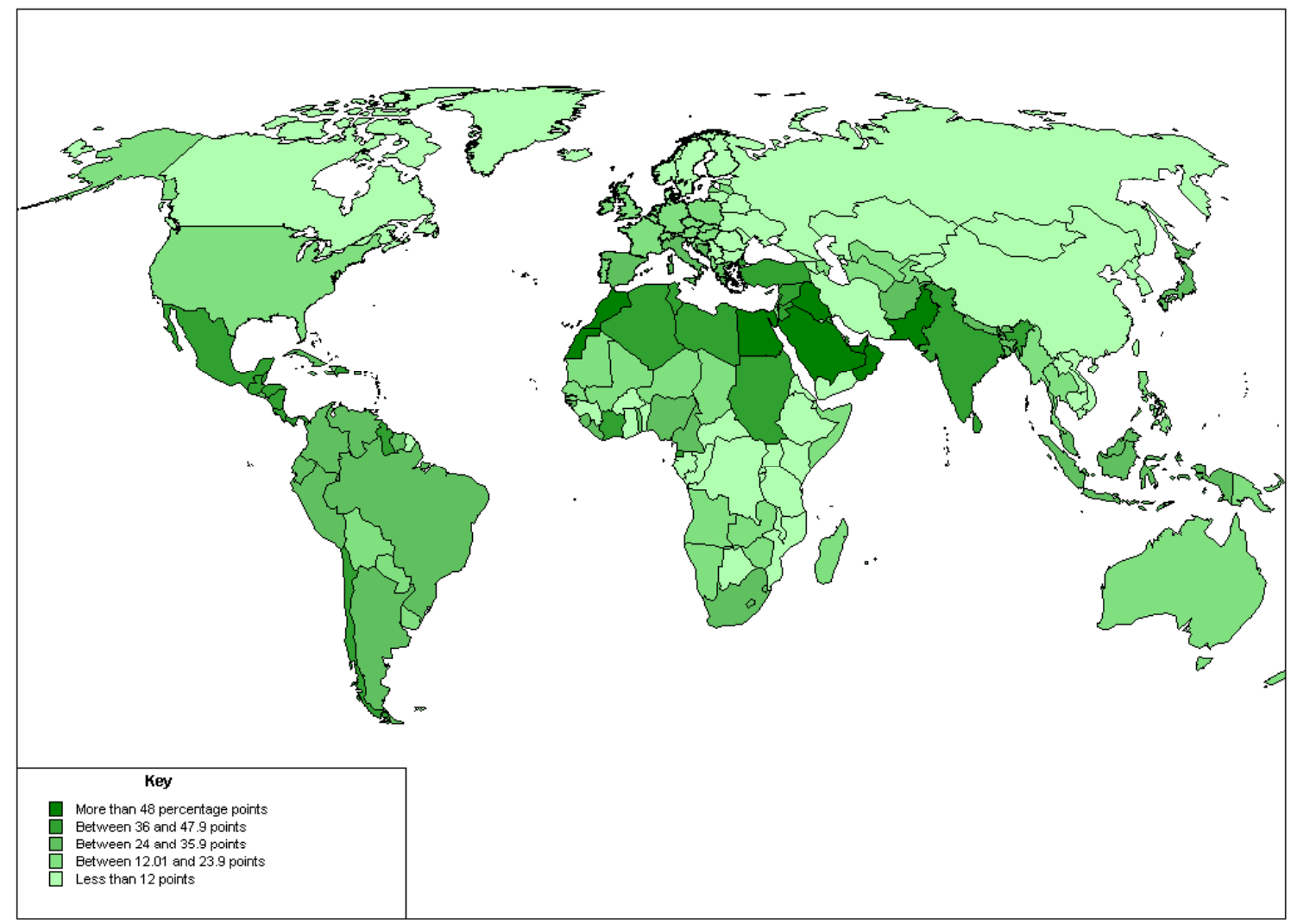

Source: ILO, Global Employment Trends Model, 2003; see also ILO, Global Employment Trends 2004, Technical note.

The biggest gap exists in the Middle East and North Africa and South Asia, once again possibly reflecting a societal lack of interest in employment for women (figure 3.3). In the Middle East and North Africa, three times more jobs exist for men compared to their population than for women, and in South Asia the share is twice as high for men than for women. The smallest gap is observed in the transition economies (where women have traditionally taken a more equal part in labour markets) and in East-Asia.

Latin America and the Caribbean region showed the biggest improvement in terms of closing the gap between male and female employment-to-population ratios. The gap in 2003 was over 6 percentage points smaller than in 1993. In all Asian regions the gaps remained almost as wide as in 1993.

One might argue that not all women of working age want to work, but the simple fact that unemployment exists indicates that there are women who want to work but are unable to find work. And since overall unemployment has been higher for women than for men, it is clear that more employment opportunities need to be created for women to satisfy their willingness to work. In addition, some of the employment gaps that remain in industrialized economies can be attributed to the fact that some women might freely choose to stay at home 
because they can afford it. But in other regions of the world it is more likely that women would work if there were opportunities for them to do so. Of course attracting more women into the labour force also requires as a first step the provision of equal access to education for women and equal opportunities in gaining the skills necessary to compete in the labour market.

\section{Trends in employment by sector and status, wages/earnings and working poverty}

No agreed-upon single indicator exists for assessing the conditions of employment. However, some insights can be gained by analyzing three indicators: status of employment, employment by sector and wages/earnings. An initial assessment of these indicators reveals that although progress has been made in terms of female labour force participation, this has not necessarily been paralleled with progress in the creation of decent work opportunities for women. There are, of course, other indicators that would be of interest - hours of work and the presence of female labour in the largely unprotected informal economy (see box 4.1), for example. However, given the difficulties in the standardization of definitions, methodology of collection and data availability, these topics are not considered.

\section{Indicator 1: Employment by status of women}

Family responsibilities are still very much assigned to women. When they have to combine child-raising activities with work activities, women are required to find a solution for balancing these two roles. Role incompatibility is likely to be a greater problem for women in wage employment, less for those in self-employment and least for contributing family workers who are unpaid (but still count as employed people according to the standard definition of employment). Unfortunately, many developing economies do not have consistent data on employment status broken down by sex. Where available, this information suggests that in the poorest regions of the world the share of female contributing family workers in total employment is much higher than men's and that women are less likely to be wage and salaried workers. Table 4.1 cites some examples.

Table 4.1

Employment by status, selected economies, latest available year

\begin{tabular}{|l|c|c|c|c|c|c|}
\hline $\begin{array}{l}\text { Economy and latest year of } \\
\text { data availability }\end{array}$ & $\begin{array}{c}\text { Wage and salaried workers } \\
\text { (employees) }\end{array}$ & \multicolumn{2}{|c|}{$\begin{array}{c}\text { Contributing family } \\
\text { workers }\end{array}$} & \multicolumn{2}{|c|}{$\begin{array}{c}\text { Self-employed } \\
\text { workers }\end{array}$} \\
& Female & Male & Female & Male & Female & Male \\
\hline Bangladesh 2000 & 8.3 & 15.2 & 73.2 & 10.1 & 11.0 & 49.8 \\
\hline Pakistan 2000 & 33.1 & 36.0 & 50.1 & 16.7 & 16.8 & 47.3 \\
\hline Cambodia 2001 & 13.6 & 19.1 & 53.3 & 31.6 & 33.0 & 40.9 \\
\hline Thailand 2000 & 38.8 & 40.2 & 39.8 & 16.4 & 21.4 & 43.3 \\
\hline Zimbabwe 1999 & 22.0 & 50.8 & n.a. & n.a. & 58.0 & 29.2 \\
\hline West Bank and Gaza Strip 2001 & 63.9 & 61.9 & 27.3 & 6.0 & 8.8 & 32.2 \\
\hline Yemen 1999 & 13.8 & 50.7 & 0.3 & 0.3 & 63.4 & 49.0 \\
\hline Egypt 2000 & 57.2 & 60.6 & 26.0 & 8.2 & 16.8 & 31.1 \\
\hline
\end{tabular}

n.a. = Data not available.

Source: ILO, Key Indicators of the Labour Market, 3rd Edition (Geneva, 2003), table 3. 
This trend is expected to continue in most parts of the developing world. Especially at times of economic crises or downturns, women are the first to withdraw from wage and salaried work. They may then be forced to enter the informal economy as own-account or unpaid family workers (see box 4.1).

Box 4.1

Working in the informal economy

The informal sector represents a significant part of the economy, and certainly of the labour market, in many economies, especially developing economies, and plays a major role in employment creation, production and income generation. ${ }^{1}$ In economies with high rates of population growth or urbanization, the informal economy tends to absorb most of the expanding labour force in the urban areas. Informal economy employment is a necessary survival strategy in economies that lack social safety nets.

Although national implementation of a universally agreed upon definition of the informal economy is still erratic there is general agreement that work in the informal economy means being outside the legal and regulatory frameworks, and is thus normally characterized by a high degree of vulnerability. Workers have little or no legal or social protection and are excluded from or have limited access to public infrastructure and benefits. Informal economy workers are rarely organized for effective representation and have little or no voice at the workplace or in the socio-political arena. Informal employment is normally unstable and insecure - consisting of very long hours and high pressure periods to finish contract orders within short deadlines, followed by "inactive" periods waiting for orders. Most informal economy employment is self-employment. There is a link - although not a perfect correlation - between working in the informal economy and being poor. This stems from the lack of labour legislation and social protection covering workers in the informal economy, and from the fact that informal economy workers earn, on average, less than workers in the formal economy.

Statistics on employment in the informal economy are essential for obtaining a clear picture of the contributions of all workers, women in particular, to the economy. Indeed, the informal economy has been considered as a possible fallback position for women who are excluded from paid employment. It is often the only source of income for women in the developing world, especially in those areas where cultural norms bar them from work outside the home or where, because of conflict with household responsibilities, they cannot undertake regular employee working hours.

${ }^{1}$ For additional information, see ILO, Women and men in the informal sector: A statistical picture, Geneva, 2002; website: http://www.ilo.org/public/english/employment/infeco/download/menwomen.pdf; as well as the ILO website on the Informal Economy at http://www.ilo.org/infeco.

Even among wage and salaried workers, more and more women are likely to be in non-regular or atypical employment. Whereas men are more likely to be hired in core or regular and better-paid positions, women are increasingly being hired in peripheral, insecure, less-valued jobs including home-based, casual or temporary work. These jobs are normally characterized by very low pay, irregular income, little or no job or income security and lack of social protection (see box 4.2).

\section{Box 4.2}

Home-based work as a solution for role incompatibility?

Although official statistics on home-based work are scarce, there is evidence that home-based work is becoming increasingly common, especially for women, due to the growing use of subcontracting and industrial outsourcing systems and the spread of ICT. Home-based workers are defined in the 1993 international Classification of Status in Employment as those who work for an enterprise to supply goods or services by prior arrangement with that enterprise, and whose place of work is not within any of the enterprise's establishments. ${ }^{1}$ Home-based workers may be classified as wage or salaried employees or self-employed.

While women may benefit from new independence in terms of work location and flexible working hours that allow them to balance work and family roles according to their own arrangements, there are growing concerns about conditions of low-pay and the lack of protection which can accompany home-based work. In addition, there is also concern that home-based work can create a sense of isolation and exclusion from career choices.

${ }^{1}$ For information on the definition and measurement of home-based work, see ILO, Bulletin of Labour Statistics, 1993-2. 


\section{Indicator 2: Employment by sector of women}

An analysis of the sectoral data gives an additional indication that women's work is not likely to be status-enhancing or empowering for them. Women have a higher share in agricultural employment in Asia, sub-Saharan Africa and the Middle East and North Africa and some economies in Latin America and the Caribbean, especially in economies with low per capita income (figure 4.1). In all developing regions women's share in industry is lower than men's. This is despite the fact that export-led industrialization has been strongly femaleintensive, particularly in the export-processing zones (EPZs) of developing economies. EPZs have created an important avenue for women to enter the formal economy at better wages than in agriculture and domestic service. However, there is evidence that as the nature of employment in EPZs evolves, with higher technology inputs, the gender profile of the workforce changes. ${ }^{3}$

Within the services sector, women are still concentrated in sectors that are traditionally associated with their gender roles, particularly in community, social and personal services, whereas men dominate the better-paid sector jobs in financial and business services and real estate.

Figure 4.1

\section{Employment distribution, by sector and sex, developing economies, latest available year}

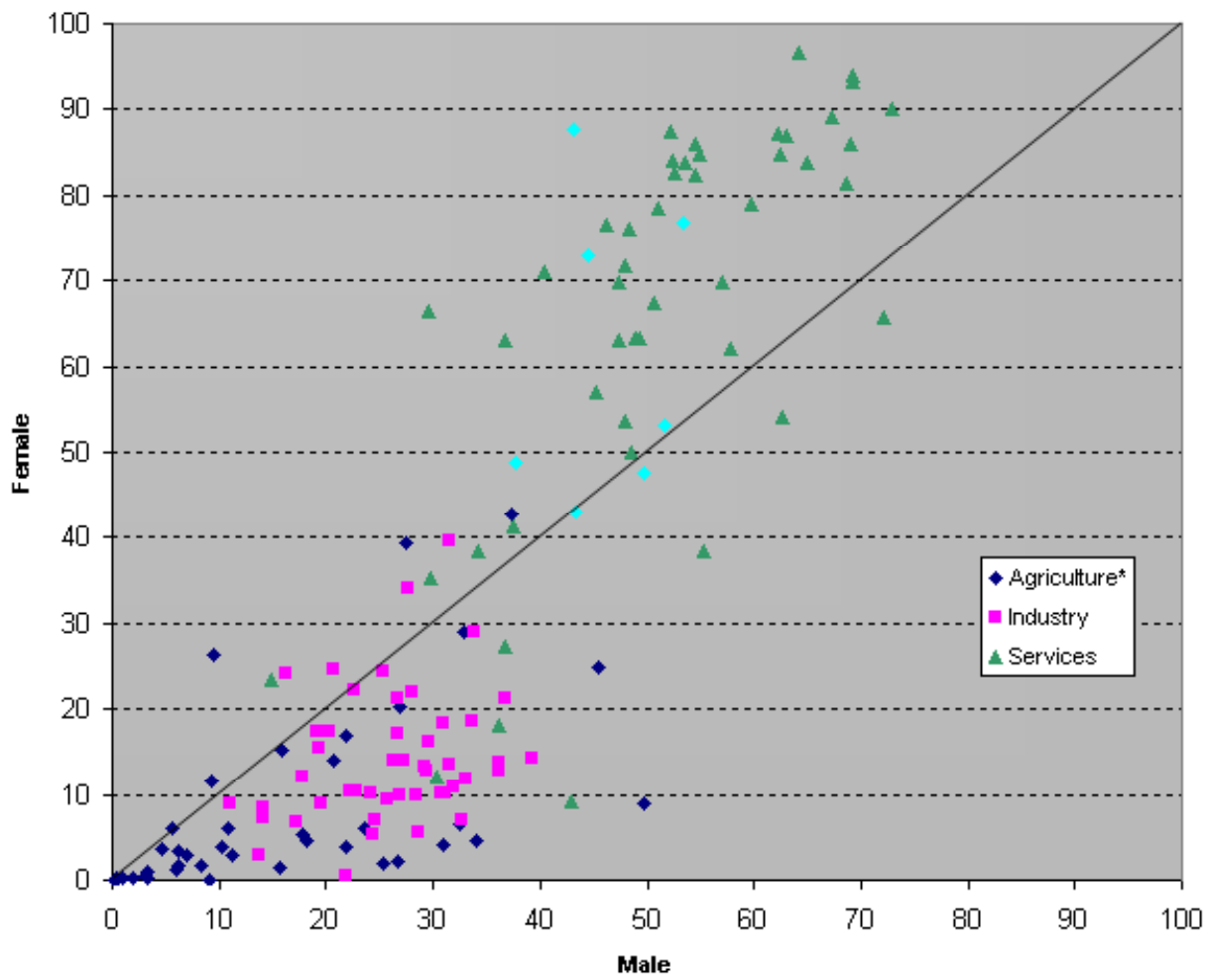

* The light-blue diamond indicates an economy in which the highest proportion of workers is employed in the agricultural sector. These include Bangladesh, Indonesia, Kyrgyzstan, Pakistan, Sri Lanka, Thailand, and Yemen.

Source: ILO, Key Indicators of the Labour Market, 3rd Edition (Geneva, 2003), table 4a.

${ }^{3}$ For more information on the employment and social implications of export-processing zones, see ILO, Governing Body Report “Employment and social policy in respect of export-processing zones (EPZs)”, GB.286/ESP/3, March 2003; available at website:

http:/www.ilo.org/public/english/standards/relm/gb/docs/gb286/pdf/esp-3.pdf. 
The sex segregation of occupations is changing, but only slowly. Female stereotypes, such as caring, docile care-giver and home-based worker, are still being reinforced and may be perpetuated into the next generation if restricted and inferior labour market opportunities for women continue to lead to underinvestment in women's education, training and experience.

\section{Indicator 3: Wages and earnings}

Can wage equality be achieved? The evidence is not favourable in the short term. Women everywhere typically receive less pay than men. This is in part because women often hold low-level, low-paying positions in female-dominated occupations. A review of data available for six diverse occupation groups shows that in most economies, women still earn 90 per cent or less of what their male co-workers earn (figure 4.2$){ }^{4}$ In a typically maledominated occupation such as welding in metal manufacturing, the wage disparities are even greater. Female welders in the industrialized economies earned, on average, 79 per cent of what male welders earned, and in developing economies even less at 75 per cent. Even in "typically female" occupations such as nursing and teaching, gender wage equality is still lacking. In Singapore, for example, male first-level education teachers earned approximately 6 per cent more than female teachers, and male nurse 21 per cent more.

Traditionally there has been greater wage equality in the transition economies than in industrialized or developing economies. This is still the case today. For example, the wages of female welders and female teachers in transition economies are nearly equitable to those of males (98 per cent of the male rate) and female nurses earned even more than their male counterparts in the same occupations (2 percentage points more than the male rate).

One might expect to find near wage equality in high-skill occupations where the education and training level of applicants would presumably be comparable (accountant in the banking sector or computer programmer in the insurance sector, for example). This is not the case. Even in these occupations the average female wage is still only 88 per cent of the male wage. One of the reasons identified for the wage differential is women's lack of negotiating capability as well as bargaining power. ${ }^{5}$

Is the situation improving? In a word, no, or at least the results are mixed according to occupation. In table 4.2, a higher percentage change for females than males in the same occupation would imply that female wages increased faster than male wages and were thus catching up to the male level. In the majority of cases where time-series analysis was possible, "catching up" did not occur. Female wages were catching up to male wages in only five of 12 economies with available data for accountants in the banking sector, four of ten economies for the computer programmers in insurance, five of 12 for teachers, six of ten for labourers, four of 11 for nurses and two of six for welders. The occupations that showed the greatest deterioration in the male-to-female wage situation over time were first-level education teacher and welder.

${ }^{4}$ In this section, "wages" refers first to wages defined as the "rates paid for normal time of work, comprising: basic wages and salaries, cost-of-living allowances and other guaranteed and regularly paid allowances". Earnings are used in countries where only data on earnings and not wages are available. Earnings extend beyond wage rates to include as well "remuneration for time not worked, such as for annual vacation or other paid leave or holidays, and including those elements of earnings which are usually received regularly, before any deductions are made by the employer in respect of taxes, contributions of employees to social security and pension schemes, life insurance premiums, union dues and any other obligations of employees.” See ILO, Statistics on occupational wages and hours of work and on food prices: October Inquiry results, 2000 and 2001 (Geneva, 2002).

${ }^{5}$ For a study on the gender difference in negotiating capacity, see Linda Babcock, et al., "Nice girls don’t ask”, in Harvard Business Review, October 2003, p. 14. 
Figure 4.2

Average female wages/earnings as percentage of male wages/earnings in selected occupations, latest available year

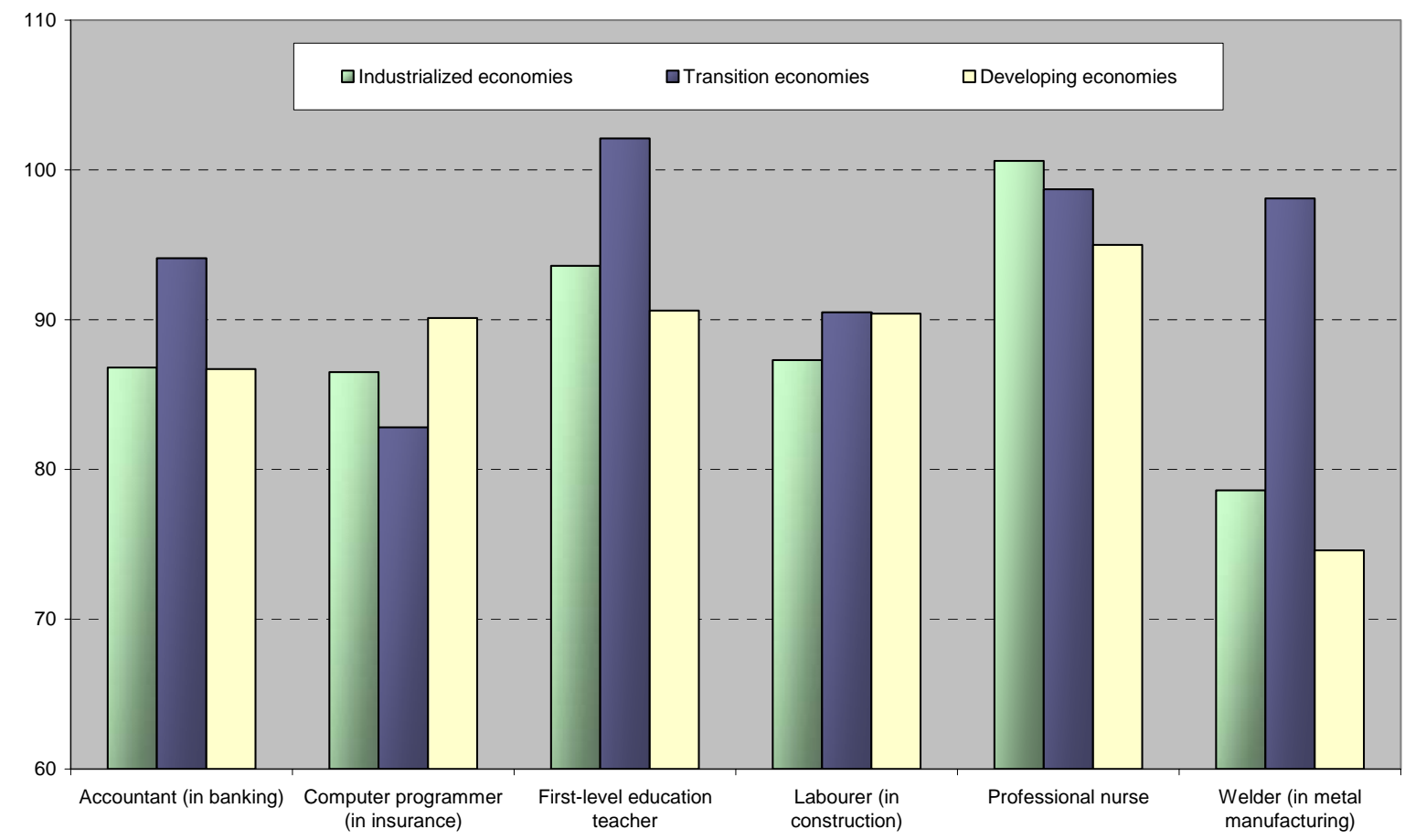

Note: Average in this chart denotes a basic average of the countries with available data; 12 economies in the industrialized economies, 17 in the developing economies and 7 in the transition economies amongst the various occupations.

Source: ILO, Key Indicators of the Labour Market, 3rd Edition (Geneva, 2003), tables 16a and 16b.

Table 4.2

Percentage change in real wages/earnings, men and women, selected occupations

\begin{tabular}{|c|c|c|c|c|c|c|c|c|c|c|c|c|}
\hline & \multicolumn{2}{|c|}{$\begin{array}{l}\text { Accountant } \\
\text { (in } \\
\text { banking) }\end{array}$} & \multicolumn{2}{|c|}{$\begin{array}{c}\text { Computer } \\
\text { programmer } \\
\text { (in } \\
\text { insurance) }\end{array}$} & \multicolumn{2}{|c|}{$\begin{array}{c}\text { First- } \\
\text { level } \\
\text { education } \\
\text { teacher }\end{array}$} & \multicolumn{2}{|c|}{$\begin{array}{l}\text { Labourer (in } \\
\text { construction) }\end{array}$} & \multicolumn{2}{|c|}{$\begin{array}{c}\text { Professional } \\
\text { nurse }\end{array}$} & \multicolumn{2}{|c|}{$\begin{array}{l}\text { Welder } \\
\text { (in metal } \\
\text { manu- } \\
\text { facturing) }\end{array}$} \\
\hline & $\mathbf{F}$ & M & $\mathbf{F}$ & M & $\mathbf{F}$ & M & $\mathbf{F}$ & M & $\mathbf{F}$ & M & $\mathbf{F}$ & M \\
\hline Bahrain (1993-98) & 16 & 16 & n.a. & n.a. & -7 & 3 & 26 & 24 & n.a. & n.a. & n.a. & n.a. \\
\hline Belarus (1996-2000) & n.a. & n.a. & n.a. & n.a. & 100 & 35 & 307 & 323 & n.a. & n.a. & n.a. & n.a. \\
\hline Cyprus (1990-2001) & n.a. & n.a. & 44 & 60 & 23 & 12 & 49 & 37 & 26 & 9 & n.a. & n.a. \\
\hline Finland (1990-98) & 67 & 96 & 44 & 66 & -7 & -4 & 1 & 8 & -7 & -6 & -10 & -1 \\
\hline Jordan (1988-97) & 29 & 20 & -63 & -51 & 25 & 13 & n.a. & n.a. & -21 & -17 & n.a. & n.a. \\
\hline Korea, Republic of (1990-2001) & 91 & 46 & 94 & 73 & 29 & 60 & 115 & 37 & 71 & 229 & 46 & 49 \\
\hline Kyrgyzstan (1998-2001) & 4 & -26 & n.a. & n.a. & -14 & -39 & 4 & 20 & -19 & -32 & n.a. & n.a. \\
\hline Latvia (1997-2001) & 39 & 31 & 561 & 142 & 82 & 45 & 36 & 18 & 60 & 33 & 1 & 26 \\
\hline Peru (1997-2001) & 15 & 35 & -13 & -20 & 34 & 37 & n.a. & n.a. & n.a. & n.a. & n.a. & n.a. \\
\hline Poland (1998-2001) & 28 & 31 & 103 & 70 & 53 & 53 & 13 & 20 & 26 & 29 & 45 & 25 \\
\hline Romania (1995-2001) & 126 & 73 & 7 & 38 & -7 & -6 & -19 & -24 & 27 & 17 & -22 & -20 \\
\hline Singapore (1995-2000) & -3 & -24 & 24 & 43 & n.a. & n.a. & 26 & 16 & 9 & 24 & 24 & 19 \\
\hline United Kingdom (1996-2001) & 16 & 19 & n.a. & n.a. & n.a. & n.a. & n.a. & n.a. & 10 & 12 & n.a. & n.a. \\
\hline United States (1990-2000) & 9 & 12 & 15 & 6 & 4 & 14 & n.a. & n.a. & -2 & 10 & n.a. & n.a. \\
\hline
\end{tabular}

n.a. = Data not available.

Source: ILO, Key Indicators of the Labour Market, 3rd Edition (Geneva, 2003), tables 16a and 16b. 
Figure 4.3 shows a specific economy example of the movement in female-to-male earning differentials over time: in the United States in 1990 the earnings of female nurses were almost equivalent to that of male nurses. By 2000, however, female nurses were earning less than 90 per cent of their male counterparts. There was a similar decrease in the earnings gap by gender for accountants in the banking sector.

Figure 4.3

Female occupational earnings as a percentage of male earnings in the United States, 1990 to 2000

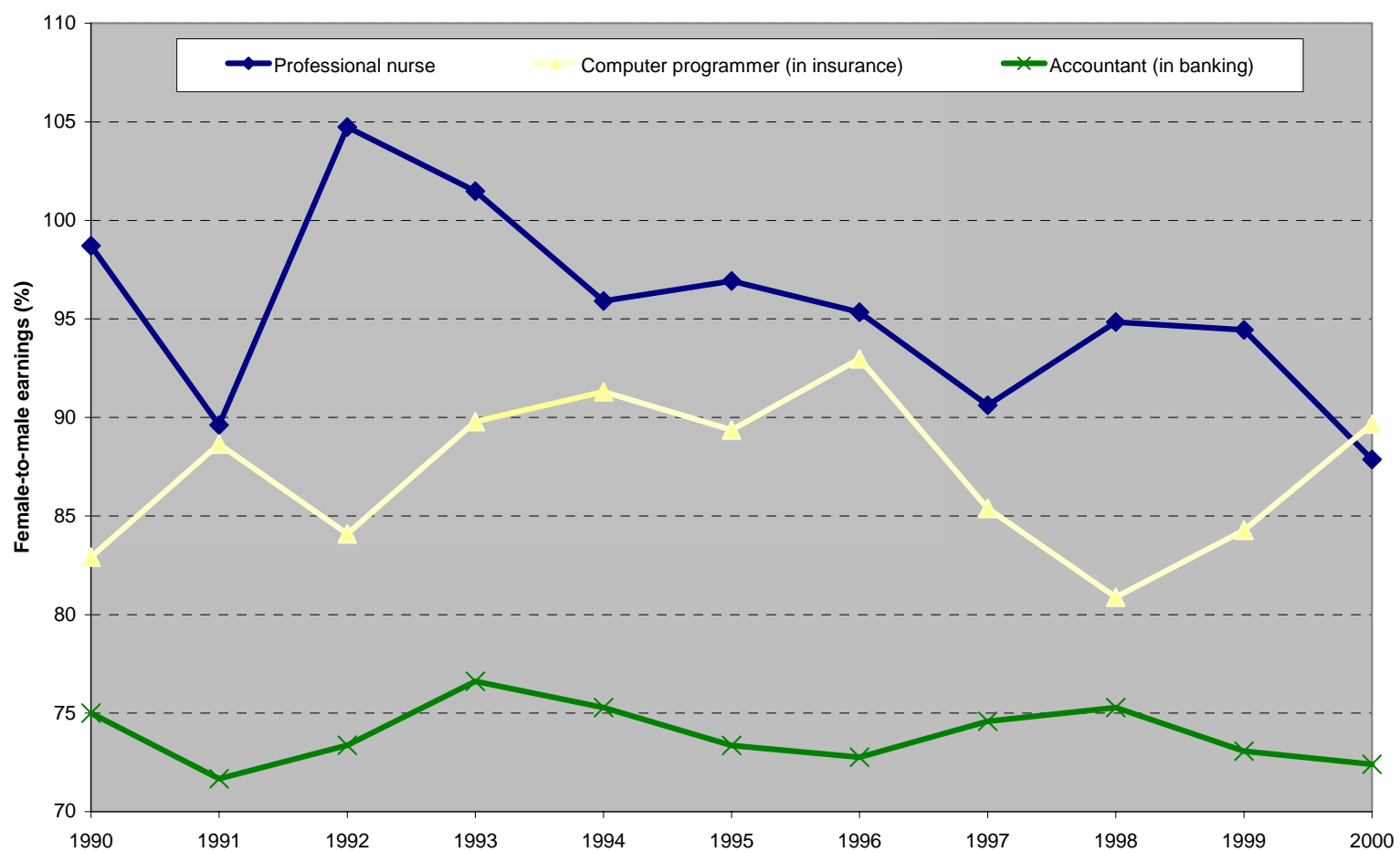

Source: ILO, Key Indicators of the Labour Market, 3rd Edition (Geneva, 2003), table 16b.

\section{Women have a high likelihood of being working poor}

The assumption that, in the process of socioeconomic development, women increasingly enter the modern sector, permanent, full-time wage employment does not hold at least not for the time being. Increases in labour force participation rates have so far not been matched by improvements in job quality and the working conditions of women have not led to their true socioeconomic empowerment.

As a result the share of women that are employed but still are unable to lift themselves and their family above the US $\$ 1$ a day poverty line - the so-called working-poor share - is higher for women than it is for men. Out of the total number of 550 million estimated working poor, around 60 per cent or 330 million are women. ${ }^{6}$ Only if future creation of decent jobs extends even more to women than to men, can this share be reduced.

There is mounting evidence that women's ability to fully enjoy human rights - indeed, even to demand such rights - is integrally linked to their economic empowerment. The ability

\footnotetext{
${ }^{6}$ The calculation of the number of people that are working poor is based on the poverty figures given by the World Bank. Unfortunately these figures don't exist disaggregated by region. But many experts assume a female poverty rate of 60-70 per cent (see footnote 1). This is the rate used for the calculation of female working poor in the world for this publication. For details on the calculation of working poor see Kapsos, S., "Estimating growth requirements for reducing working poverty: Can the world halve working poverty by 2015”, Employment Paper (Geneva, ILO, forthcoming).
} 
to take decisions - on marriage, on childbearing and on contraception, among others requires a sense of personal autonomy, which develops in tandem with the self-knowledge that women can provide for themselves and their children. Their sense of personhood is sparked by motherhood and nurtured by participation in organized groups, but fundamentally depends on having their own decent income. Whether women work out of need or choice, the focus should be on giving them decent jobs, so that in the long run they can work themselves and their families out of poverty. At the same time childcare facilities are a necessary precondition for women to be able to go to work and use their productive potential effectively. 